\title{
ARENITE CONCRETIONS WITH AXIAL CHANNEL FROM THE BADENIAN DEPOSITS OF CHEIA (TURDA) - A NEW TYPE OF CONCRETIONS ${ }^{1}$
}

(In memoriam Prof. Valeriu Lucca)

\author{
IOAN MÂRZA ${ }^{2}$, CIPRIAN CONSTANTINA ${ }^{2}$, HOREA PÂRLEA ${ }^{2}$
}

\begin{abstract}
The paper introduces a new type of arenite concretions (max. $40-50 \mathrm{~cm}$ in diameter). Spheroidal concretions with an axial cylindrical channel (1-6 cm in diameter) resulted from the levigation of the concretion centre consisting of soft fusiform clasts with a clayey-carbonate composition. The concretions are hosted by a level of Badenian sandstones and microconglomerates (about 10-m thick) which occur in the place called "Groapa cu Piersici" (Cheia, Turda).
\end{abstract}

Key words: arenite concretions with axial channel, soft clasts, Badenian

Concretions in general, and the arenite ones in particular, show variable morphologies. Spherical, discoidal, cylindrical, irregular, simple or joined concretions were previously described. There are also differences concerning the mineralogicalpetrographical composition, the genetic characteristics and the geological age. In Romania, several studies were aimed to identify and describe different types of concretions: arenitic (Nicorici, 1957; Chintă uan, 1994; Chintă uan \& Codrea, 2000), carbonatic - biogenic-phytogenic (Dragastan, 1980) or abiotic (Georgescu, Frunzescu, 1983), siliceous (Mârza, Ghergari, 1963, Mârza et al., 1997, Ghiurca, Tudoran, 1997, Ghiurca, 2000), sulphatic (Stoicovici, Mureșan, 1964; Alexandrescu, Rogge-Taranu Elena, 1978) etc. These studies tried to explain the concretion formation phenomenon, which is in general similar. Local geological variations of a lithostratigraphical and diagenetic nature determine specific fetaures of the concretions: morphological diversity, size variations and diverse mineralogicalpetrographycal compositions. The general law of formation corresponds to the cementation of siltic-arenitic particles or sometimes ruditic particles around a carbonate concretion centre in the case of detrital products. In the case of concentric precipitation from colloidal solutions the process is represented by the accretion of gels.

Concretions in general, and the arenitic ones in particular are a typical example of "Art" within geology. There is large diversity of extremely curious shapes, sometime bizarreries (anthropomorphic, zoomorphic imitations). Thus,

${ }_{1}$ Presentation on the occassion of the Anniversary Symposium "Prof. Valeriu Lucca (19011969) - 100 years from his birth", 1-2 June 2001, Cluj-Napoca.

${ }^{2}$ Babeș-Bolyai University, Faculty of Biology and Geology, Department of Geology, Str. M. Kogă Iniceanu, 1, Cluj-Napoca. 
one should admit that Nature is the greatest artist, and that during centuries, mankind was inspired by it - from the Pleistocene paintings in the caves to the pieces of art of the future. The geological phenomenon is the first and most skilful artist, and the tool is the process: exogenous-sedimentary, volcanicmagmatic, metamorphogenic, tectonic, and combinations of these, sometimes in relationship with external modelling factors.

This paper presents -as far as we know for the first time - a new type of arenite concretions with an axial channel. At first sight, these have the appearance of archaeological, Neolithic artefacts (fragments of grinding moulds, weights for fishing nets etc.) rather than that of geological formations.

Occurrence and geological setting. The arenite concretions with an axial channel were identified in a torrent, in the place called "Groapa cu Piersici" (Morii Hill) on the left riverside of Arieș, in the area of Cheia-Turda, Cluj county (fig. 1). The geological formations of this region are represented by an "ophiolitic" (Mesozoic) basement, followed by Jurassic (Tithonic) limestones (Cheile Turzii = Turzii Gorges were modelled in these rocks), Badenian, Sarmatian and Quaternary formations. The outcrop with concretions (Morii Hill) consists of porphyrites belonging to the Mesozoic volcanic complex, overlaid by transgressive Badenian sediments represented by sandstones, an alternation of microconglomerates-conglomerates, poorly consolidated and friable. The latter represent a "littoral detrital facies" (Ilie, 1952). The cross bedding, the degree of sorting and rounding of the clasts indicates a torrential littoral sedimentation regime (PI. I, fig. 2).

The clasts within the microconglomerates and conglomerates are mainly represented by Mesozoic volcanic rocks (ophiolitic type), Tithonic limestones and crystalline rocks. The average size of the clasts ranges between $1-4 \mathrm{~cm}$ diameter. Some rounded blocks of porphyrites ( $80 \mathrm{~cm}$ in diameter) and Tithonic limestones $(35 \mathrm{~cm}$ in diameter) that are sporadically present in the cross-bedded sediments represent the exceptions. Rarely, rounded (reworked) fragments of lithothamnium, ostreides, and accidentally vertebrates are also to be found.

The structure of a concretion refers to the concretion proper and the concretion centre.

The concretions - are localised in a bank of coarse microconglomerates - sandstones. The thickness of individual layers in the littoral-detrital facies hosting the concretions varies from a few centimetres to tens of centimetres, rarely being larger than $1 \mathrm{~m}$. The bank in the studied outcrop is about $50 \mathrm{~m}$ long and about $10 \mathrm{~m}$ thick. The concretions were formed by cimentation of detrital particles (lithoclasts, crystaloclasts) around soft and agglutinated, fusiform clasts Morphologically, the arenite concretions show ellipsoidal shapes. They are easily detached from the host-rock by erosional processes - the rock being slightly cemented and friable. The concretions separate into several (usually 34) fragments along stratification planes marked by thin clay layers. The thin clay levels $(<1 \mathrm{~cm})$ mark an interruption of concretion formation; the process continues within the gresous-microconglomeratic layers, thus resulting spheroidal concretions built-up of several segments. The discoidal segments correspond 
to the central part of the concretions, while the conical ones to the endings (fig. 1). After the erosional removal of the concretion centres (soft clasts, agglutinated soft clasts) an axial channel with a cylindric profile is formed in the case of the central segments, and one with a conical profile in the case of the peripheral segments (fig. 1). The position of the axis inside the concretions depends on the orientation of the concretional centre within the sediment; it is usually slightly oblique from the vertical, but concretions with a horizontal axis were also identified (PI. II, figs. 3,4; PI. III, figs. 5, 6; PI. IV, figs. 7, 8). Rarely also twinned concretions formed, that can be identified based on the doubled channels. The best developed specimens are about $40-50 \mathrm{~cm}$ in diametre, but the average size is $20-30 \mathrm{~cm}$ in diameter. The smallest ones are $<10 \mathrm{~cm}$ and they also show an axial channel. Along the torrent from "Groapa cu Piersici" (Morii Hill) and at the base of the slope next to the major valleyside of Ariess river fragments of discoidal and conical concretions accumulate gravitationally.

Petrographically, the concretions correspond to a fine- to medium granular, poorly cemented grey polimictic microconglomerate (orthoconglomerate), containing subrounded lithoclasts with rounded margins and glossy surface cought in a fina carbonate detrital matrix. The size of the lithoclasts is in average 1-4 $\mathrm{mm}$ in diameter, but smaller clasts are also frequent; only rarely larger clasts can be noticed. The clasts represented by fragments of Mesozoic volcanic rocks - andesite, basaltoid andesite with a fluidal texture, dolerite-microdolerite, hialoclastite $(1.8 \times 2.0 \mathrm{~mm})$, porphirite - plate-like fragments of bentonitized Mesozoic volcanic rocks (about $1 \mathrm{~cm}$ in diameter), or of volcanic rocks with fuchsite (greenish-blueish), amigdaloid spherules of chalcedony $(0.3-0.4 \mathrm{~mm})$ erosionally separated from ophiolites of "mandelstein"-type. Rarely well-rounded fragments of white, sometimes graphite-containg quartz were noticed, that suggest a long transport or reworking during a secondary sedimentary cycle. Crystaloclasts are subangular to subrounded: fragments of basic plagioclases partly argillized, pyroxenes, quartz, muscovite, rarely garnets, metallic minerals (oxides and sulfides).

The autigenous components - identified by the means of a lens, are: fine lamellae of hematite concentrically arranged around volcanoclasts, calcite along the fissures, iron hyroxides, clay minerals from the transformation of feldspars, rarely chlorite.

The concretion centre - represents a clayey-carbonate deposit with a fusiform shape, consisting of soft clasts and soft agglutinated clasts. It is formed of a clayey-marly mass that chaotically embedds microlithoclasts and crystaloclasts (Mesozoic volcanic rocks, Tithonic limestones, metamorphic rocks, quartz). The soft clasts represent fragments of reworked intraformational marls that took a fusiform shape due to the action of the waves in the shore area. The agglutinated soft clasts resulted by the incorporation of detrital particles (lithoclasts, crystalolithoclasts) within a clayey-marly mass, still under the action of waves. The length of the soft clasts inside the concretions from Cheia (Turda) usually ranges between $10-20 \mathrm{~cm}$, while the diameter between 2-6 cm; the diameter of the axial channel is also $2-6 \mathrm{~cm}$ in length, if not amplified erosionally. 
Conclusions. The gresous concretions with an axial channel from Cheia (Turda) are epigenetic products within Badenian sandstones and microconglomerates (a torrential littoral facies). The process of formation was related to centres of fusiform soft clasts, or of $\mathrm{CaCO}_{3}$-rich soft agglutinated clasts. The erosional levigation of the concretional centre caused the formation of the cylindric axial channel with conic endings.

Aknowledgements. The authors would like to thank Lecturer Că lin Tă maș, $\mathrm{PhD}$, who kindly photographed the geological occurrences presented in this paper. We would also like to thank Prof. Bogdan Onac, PhD, for reading this paper and providing useful suggestions.

\section{REFERENCES}

Alexandrescu, Gr., Rogge-Ță ranu, Elena (1978). Concreț iuni feruginoase din Pont ianul din partea de vest a Banatului. D.S. Inst. Geol. Geofis., LXIV/1 (1976-1977), 205-214, Bucuresti.

Chintă uan, I. (1994). Consideraț ii privind formarea concreț iunilor grezoase. Rev. Bistriț ei, VIII, Muz. Bistriț a-Nă să ud, 271-284, Edit. Glasul Bucovinei, lași.

Chintă uan, I., Codrea, V. (2000). Aceste pietre stranii. Edit. Supergraph, 73 p., Cluj-Napoca.

Dragastan. O. (1980). Alge calcaroase din mezozoicul și terț iarul României. Edit. Acad. R. S. România, 169 p., București.

Georgescu, O., Frunzescu, D. (1983). L'étude minéralogique des concrétions calcareuses de Lias de Cristian. Bul. Inst. Petrol Gaze, Ploiești, XXXV/2, 41-51, Ploiești.

Ghiurca, V. Tudoran, V. (1997). Septariile silicioase din calcarele de Rona. Stud. și Cerc. III, 73-79, Muz. Jud. Bistriț a.

Ghirca, V (2000). Septaria siliceux de Roumanie. Minéraux et Fossiles, 285, 25-30, Paris.

llie, D. M. (1952). Bassin de la Transylvanie Recherches géologiques dans la région ClujCojocna-Turda-Ocna Mureșului-Aiud. An. Comit. Geol, XXIV-XXV, 177-181, București.

Mârza, I., Lucreț ia Ghergari (1963). Observații privind silicolitele din creta senoniană din Dobrogea de Sud. Studia Univ. Babeș-Bolyai, 2, 7-14, Cluj-Napoca.

Mârza, I., lonescu Corina, Bodnariuc, A. (1997). Piroclastite mezozoice cu silicolite de la Poiana Aiudului (Munții Trască ului - Apuseni). Studia Univ. Babeș-Bolyai, Geol., 1, 81-94, Cluj-Napoca.

Nicorici, E. (1957). Concreț iunile de Feleac. Descrierea și geneza lor. Rev. Natura, IX/3 3142, București.

Stoicovici, E., Moț iu, A. (1957). Date noi în legă tură cu câteva ză că minte de gips din regiunea Cluj. Bul. Univ. Babeș-Bolyai (Ș. Natur.), 1/1-2, 303-313, Cluj-Napoca.

Stoicovici, E., Mureșan, I. (1964). Studiul ză că mântului de limonit oolitic și de glauconit din formaț iunile eocene ale Bazinului Transilvaniei (I). Studia Univ. Babeș-Bolyai (Geol.Geogr.), 1, 7-16, Cluj-Napoca.

Stoicovici, E., Petreuș, I. (1969). Studiul piritelor autigene din oligocenul Maramureșului. Stud. Cerc. Geol.-Geofiz.-Geogr. (Ser. Geol), 14/2, 317-336, București.

Turculeț , I. Olaru, L. (1978). Asupra prezenț ei unor septarii în wildflișul eocretacic din Munt ii Perșani. Anal. Șt. Univ. "Al. I. Cuza: lași (Secț . II, b). Geol.-Geogr., XXIV, lași.

Udubașa, Gh. (1984). Iron Sulphides in Sedimentary Rocks Some Occurences in Romania. In: Syngenesis and Epigenesis in the Formation of Mineral Deposits. (Ed. A. Wauschkuhn, C. Kluth, R.A. Zimmermann). Springer-Verlag, Berlin, 28-35. 


\section{PI. I}
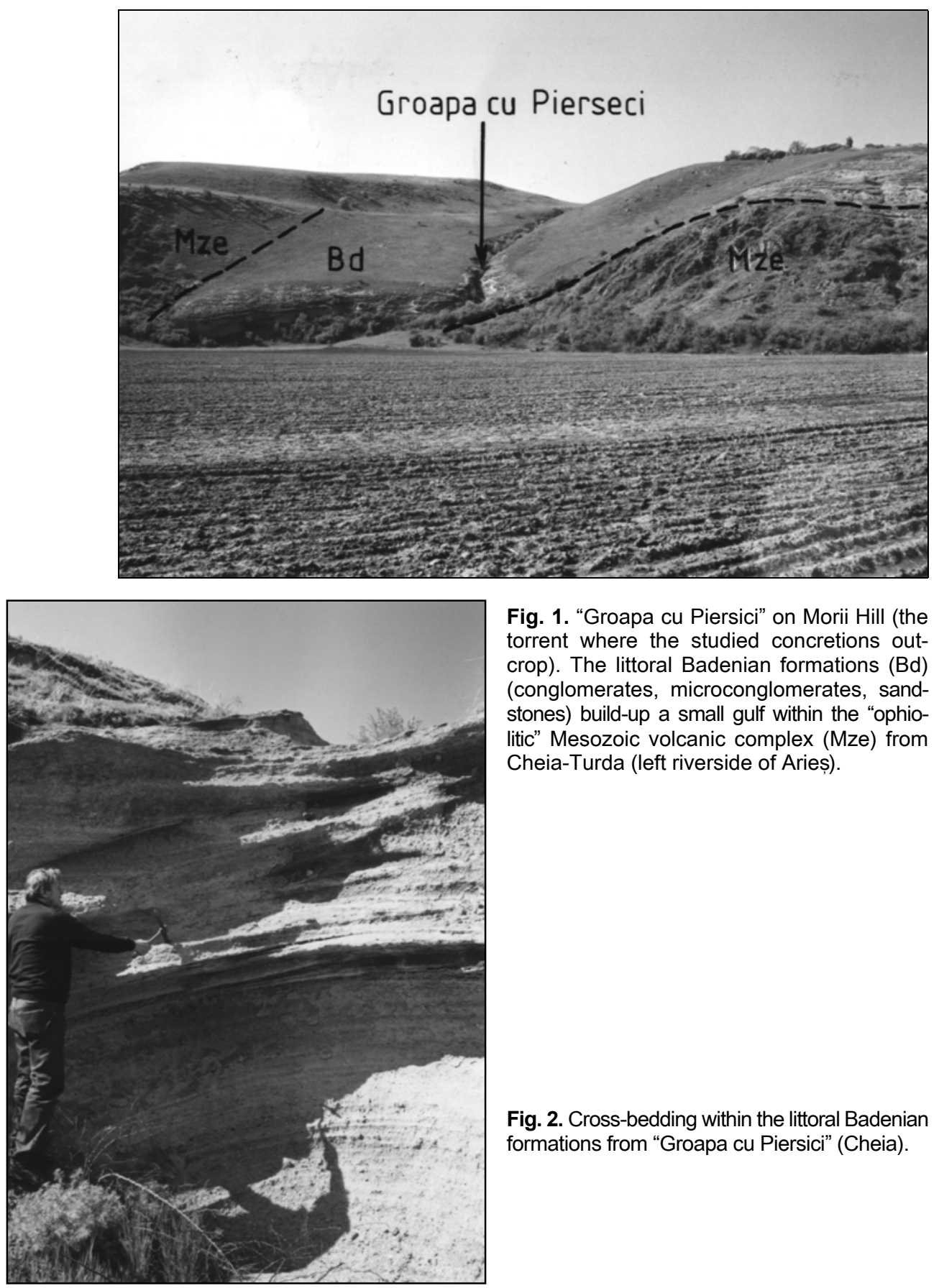

Fig. 1. "Groapa cu Piersici" on Morii Hill (the torrent where the studied concretions outcrop). The littoral Badenian formations (Bd) (conglomerates, microconglomerates, sandstones) build-up a small gulf within the "ophiolitic" Mesozoic volcanic complex (Mze) from Cheia-Turda (left riverside of Arieș).

Fig. 2. Cross-bedding within the littoral Badenian formations from "Groapa cu Piersici" (Cheia). 


\section{PI. II}

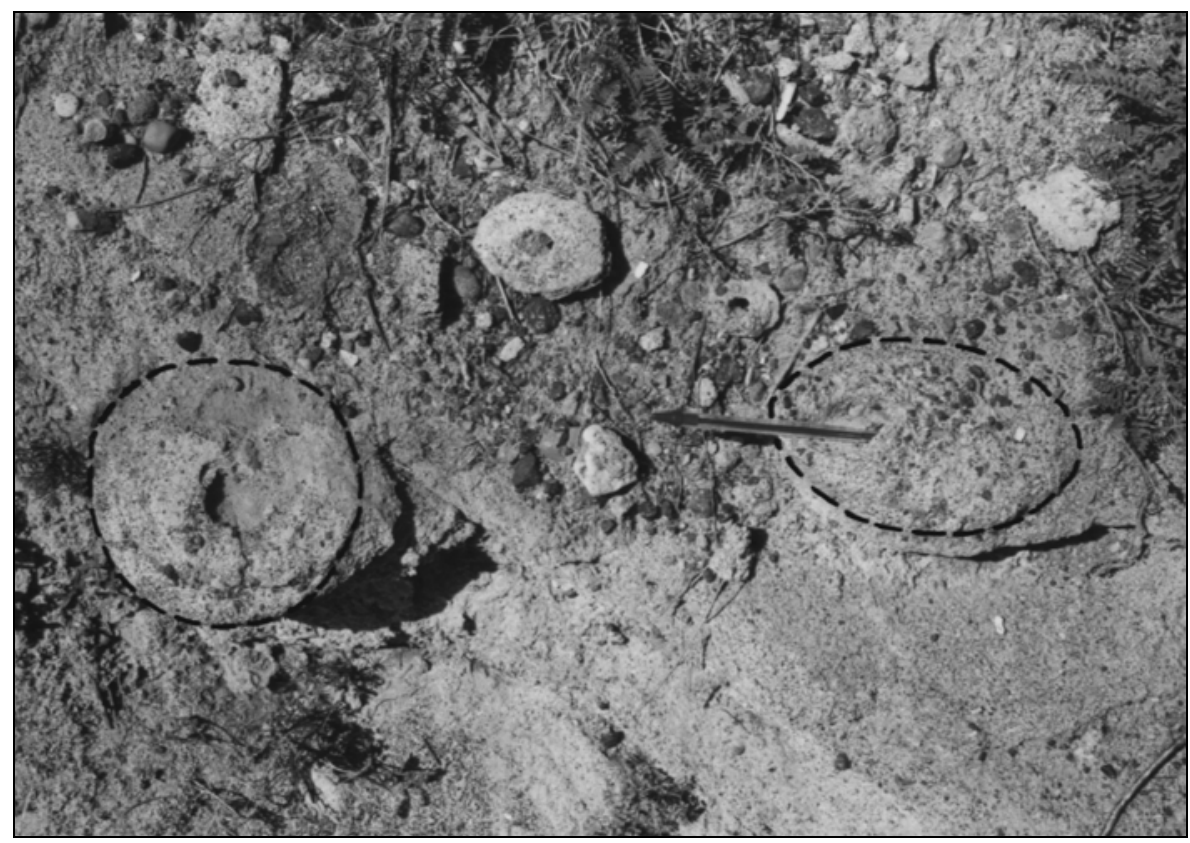

Fig. 3. An outcrop with concretions (Groapa cu Piersici). The vertical, and rarely oblique (see pen as a marker) axial channel of the concretions can be noticed.

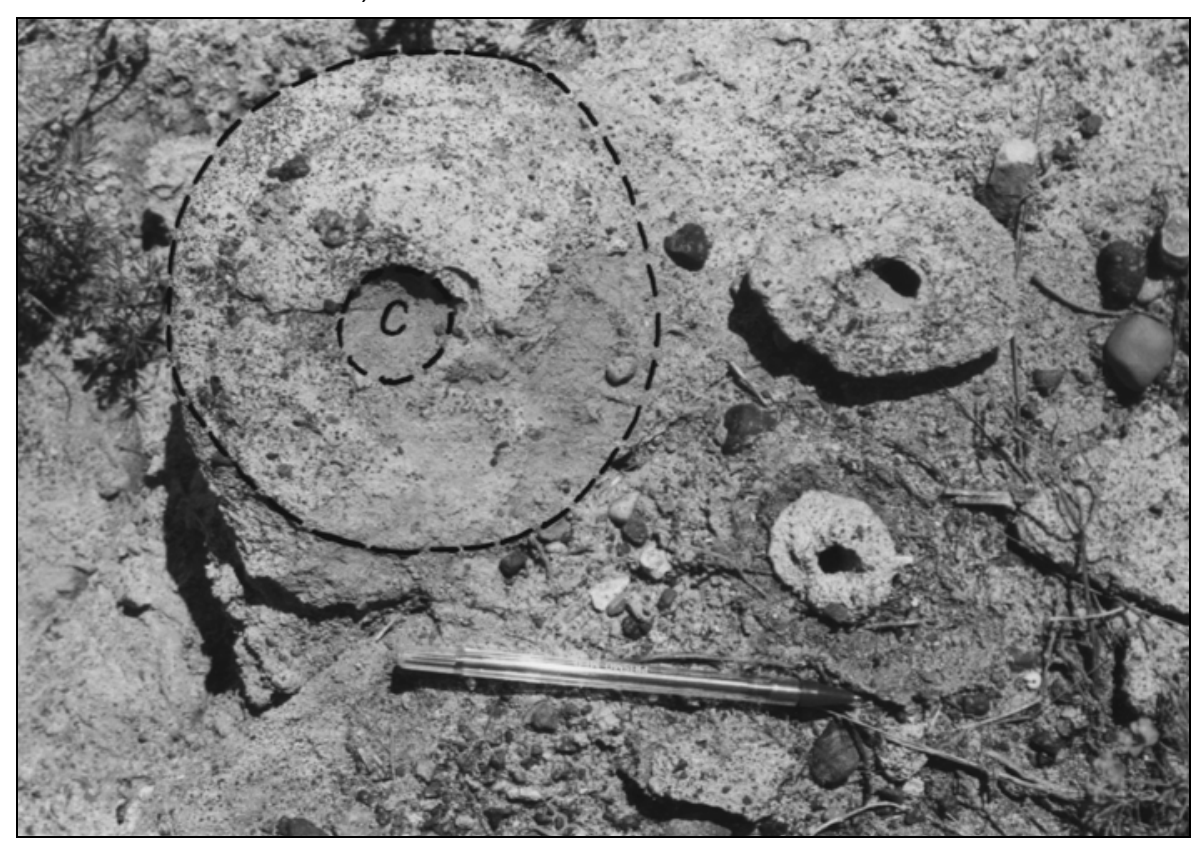

Fig. 4. In situ concretions; C - concretional centre (perpendicular section). 


\section{PI. III}

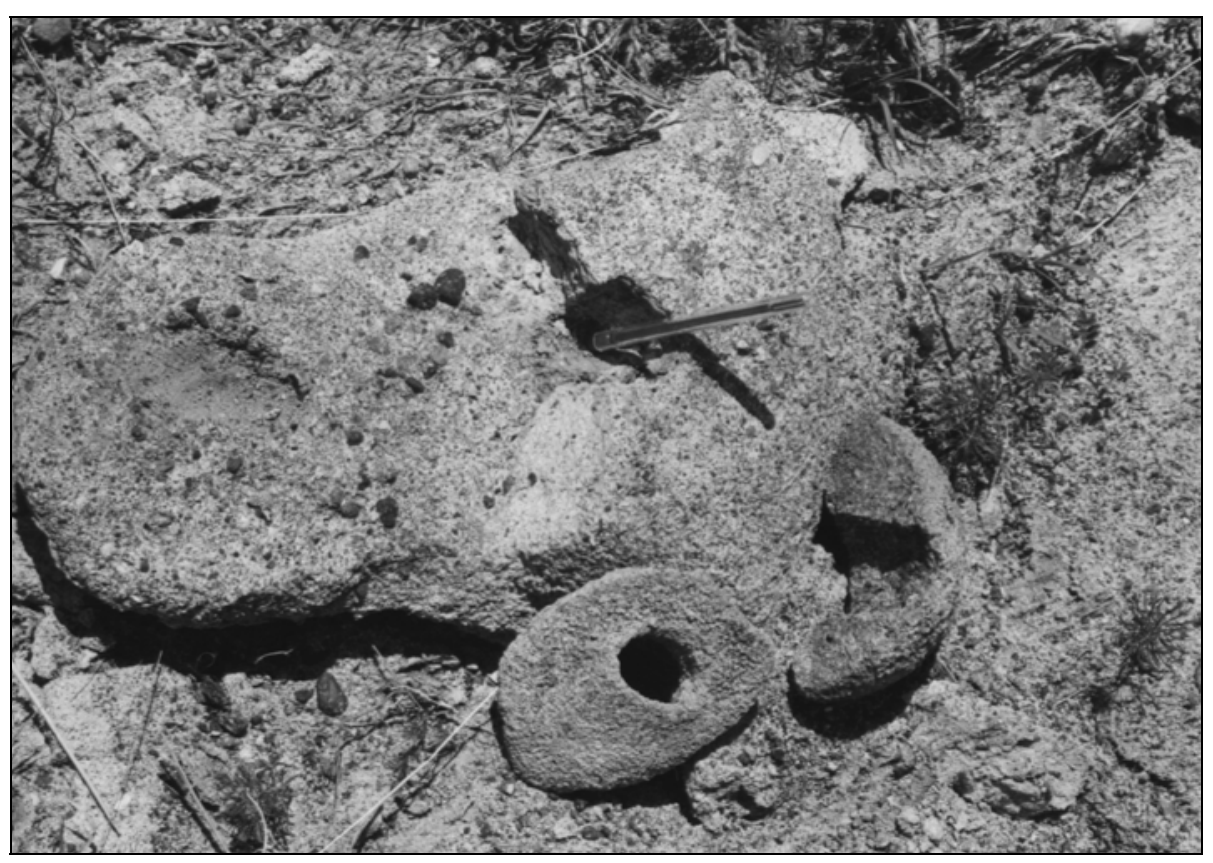

Figs. 5, 6. Fragments of concretions with an axial channel detached from the host-rock.

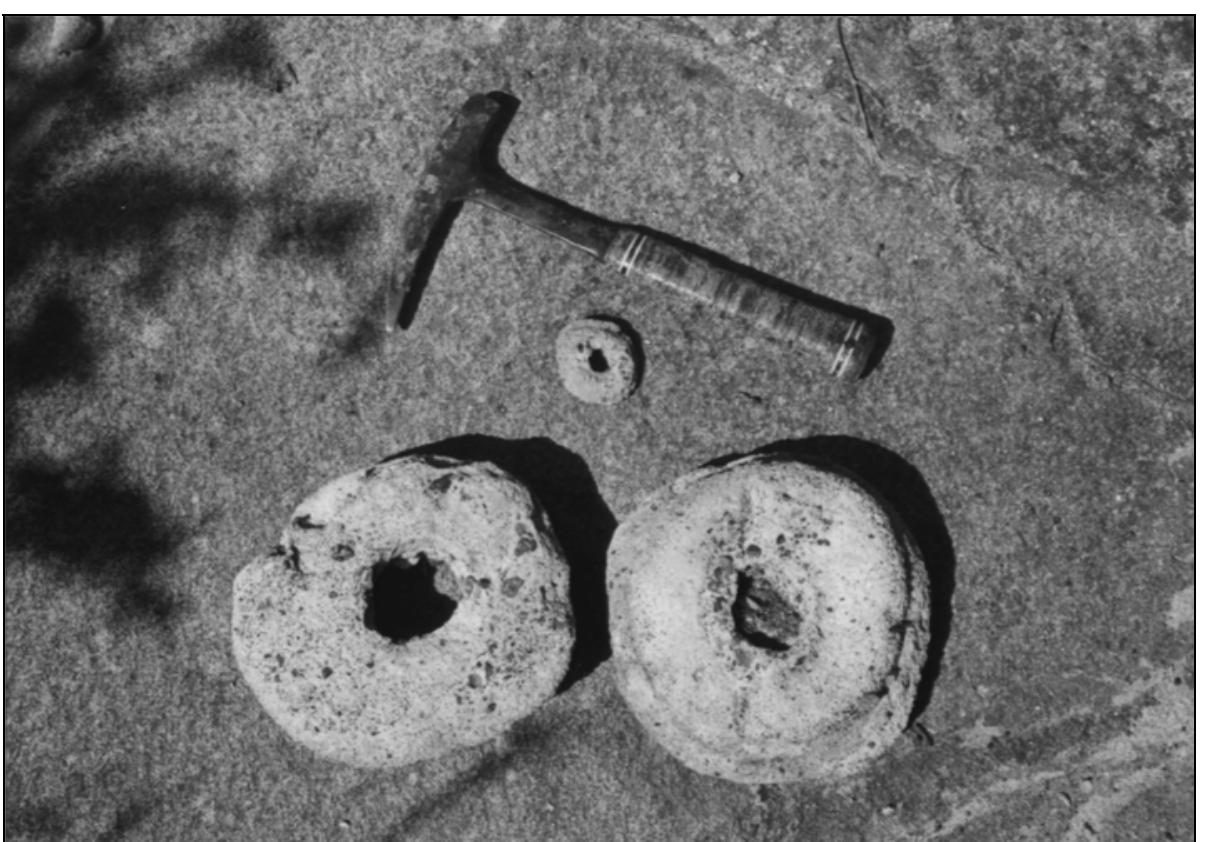




\section{PI. IV}

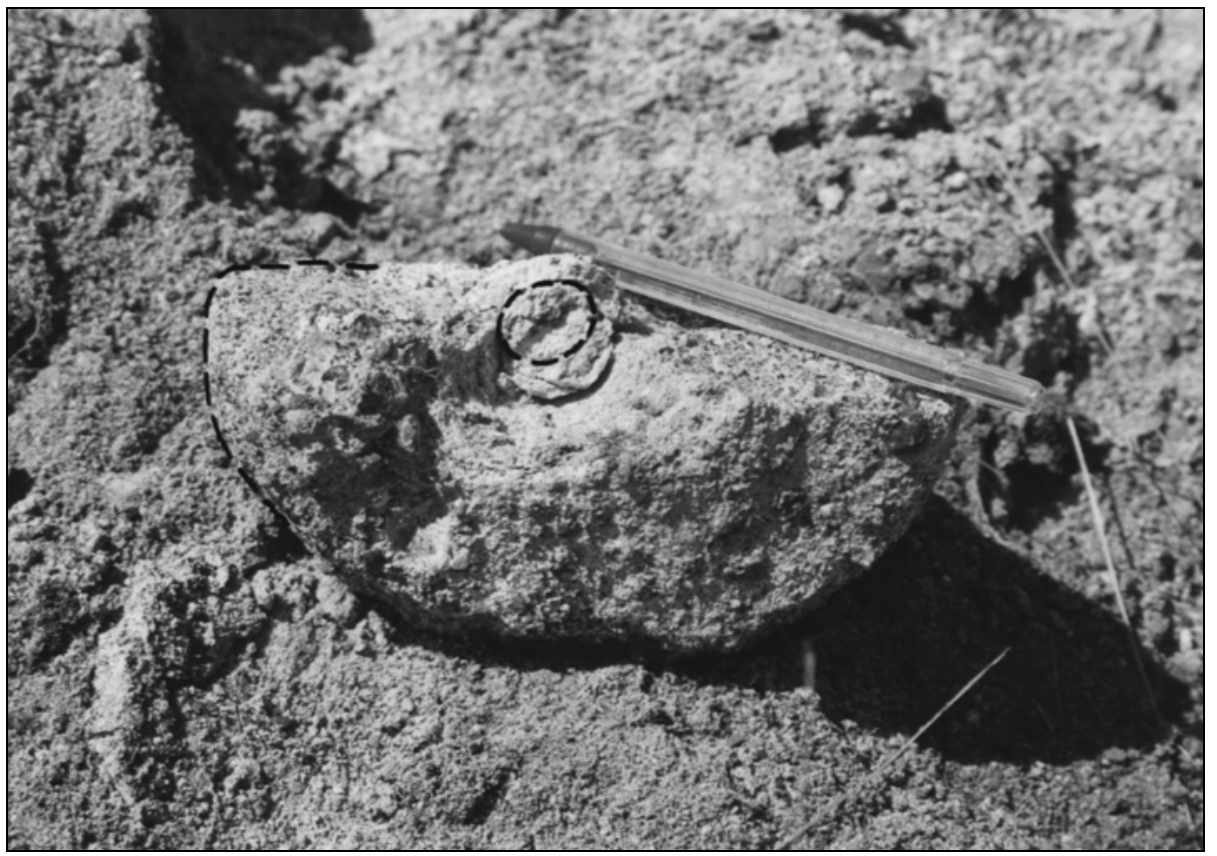

Figs. 7, 8. Fragments of concretions preserving the fusiform central part constitued of soft clasts.

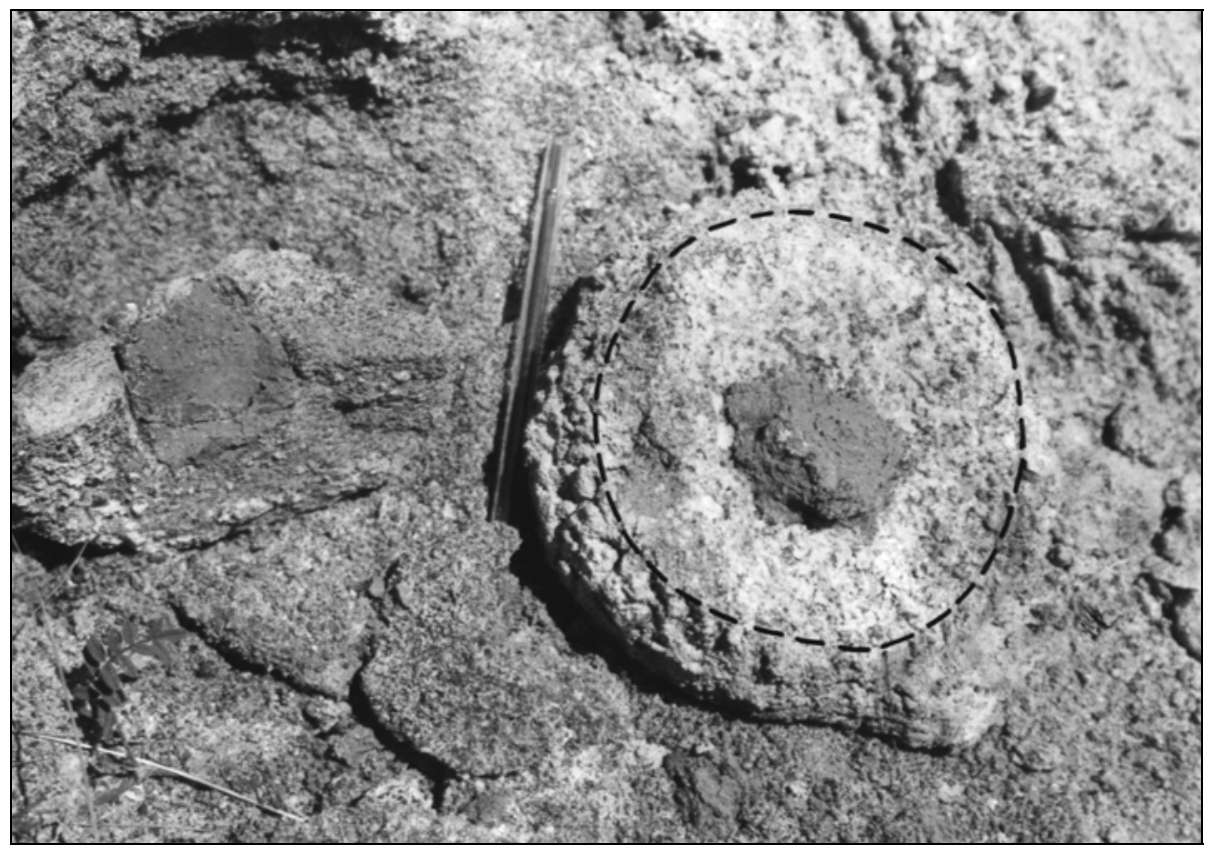

92 